\title{
"The use of social media in reducing professional uncertainty: an exploratory study"
}

\begin{tabular}{|c|c|}
\hline AUTHORS & Stavros Papakonstantinidis (D https://orcid.org/0000-0002-7273-0235 \\
\hline ARTICLE INFO & $\begin{array}{l}\text { Stavros Papakonstantinidis (2017). The use of social media in reducing } \\
\text { professional uncertainty: an exploratory study. Nowadays and Future Jobs, 1(1), } \\
6 \text {-13. doi:10.21511/nfj.1.2017.01 }\end{array}$ \\
\hline DOI & http://dx.doi.org/10.21511/nfj.1.2017.01 \\
\hline RELEASED ON & Tuesday, 26 December 2017 \\
\hline RECEIVED ON & Thursday, 12 October 2017 \\
\hline \multirow[t]{2}{*}{ ACCEPTED ON } & Tuesday, 19 December 2017 \\
\hline & \begin{tabular}{|l|}
$(c))$ EY-NC \\
\end{tabular} \\
\hline LICENSE & $\begin{array}{l}\text { This work is licensed under a Creative Commons Attribution-NonCommercial } 4.0 \\
\text { International License }\end{array}$ \\
\hline JOURNAL & "Nowadays and Future Jobs" \\
\hline ISSN PRINT & $2544-2287$ \\
\hline PUBLISHER & LLC "Consulting Publishing Company "Business Perspectives" \\
\hline FOUNDER & Sp. z o.o. Kozmenko Science Publishing \\
\hline & ニニニ \\
\hline NUMBER OF REFERENCES & NUMBER OF FIGURES \\
\hline
\end{tabular}

(C) The author(s) 2023. This publication is an open access article. 
Stavros Papakonstantinidis (Kuwait)

\title{
The use of social media in reducing professional uncertainty: an exploratory study
}

\begin{abstract}
The born-digital youth are likely to experience substantial career uncertainty despite their apparent preference for work engagement. Today's high unemployment rates, fierce global competition, growing labor automation, and enduring social inequalities create a somewhat uncertain and risky professional reality. How do digital natives deal with professional uncertainty during their transition from the safety of the university environment to the uncertainty of business? While a great deal of research has explored how recruiters use social media to review job applicants, less is known how digital natives use social media in seeking information to increase their employment prospects. The objective of this exploratory study is to contribute to the existing literature of critical studies on youth transitions from education to work. Primarily, a discussion of the characteristics of the new breed of job candidates who are born and raised digital is performed through a secondary literature review. Also, the current review paper provides suggestions for future research to better understand digital natives' attitude to cope with occupational uncertainty. This paper argues that social media has the potential to reduce uncertainty and to offer unique occupational opportunities through online personal branding.
\end{abstract}

Keywords: digital natives, personal branding, social media recruitment, uncertainty reduction theory, youth transitions. JEL Classification: O15, O33.

Received on: $12^{\text {th }}$ of October, 2017.

Accepted on: 19 $9^{\text {th }}$ of December, 2017.

\section{Introduction}

Youth, nowadays, are more aware and engaged in dealing with growing occupational uncertainties than ever before (Lechner et al., 2016). However, young people are uncertain about their professional future as the quest to find a safe career path has become increasingly complicated (Bohlinger et al., 2015). According to the annual Jobvite (2016) job seeker nation survey, nearly $39 \%$ of the currently employed workers worry that eventually automation will replace them at work and $74 \%$ openly admit that they are open to seeking new employment. This review paper contributes to the existing literature of scholarly articles discussing how young people deal with uncertainty during their transition from education to work (Carr, 2016; Lechner et al., 2016; Walker et al., 2013). It also provides a framework for further studies to suggest how college graduates can use social media and personal branding to deal with occupational uncertainties.

The rapid proliferation of the internet and social media is shaping a new reality in the contemporary employment landscape. Both recruiters and job candidates agree on the social media's high impact on professional opportunities. Morrison (2015) reports that $92 \%$ of recruiters review candidates' social media accounts to select high-quality employees.

(C) Stavros Papakonstantinidis, 2017.

Stavros Papakonstantinidis, Doctor of Social Sciences, The American University of the Middle East, Kuwait.

This is an Open Access article, distributed under the terms of the Creative Commons Attribution-NonCommercial 4.0 International license, which permits re-use, distribution, and reproduction, provided the materials aren't used for commercial purposes and the original work is properly cited.
Job candidates also seek more information before applying or accepting a job offer to reduce uncertainty by using the social media (Carr \& Walther, 2014).

A significant number of academic studies investigate how companies integrate social media into their recruitment and selection strategies to "predict an individual's potential to perform job-related tasks and compliment the social structure of the organization" (Carr, 2016, p. 53). In contrast, there is limited literature about how job candidates use social media to reduce their uncertainty during the job seeking process. The transition from the "safe" educational environment to the "unknown" and "scary" professional world generates feelings of anxiety and fear.

The current labor landscape is more complicated than ever. Approximately there are two billion social media users worldwide, and these figures will grow as people are using mobile devices and wearable technologies (most famous social network sites worldwide as of September 2017). The annual survey by Jobvite (2016) reveals that the modern job seeker can employ various methods to find the perfect job. Social media is substituting and sometimes replacing traditional methods of recruitment. The latter survey shows that only $24 \%$ of the respondents believe that the traditional employee referrals helped them find their job.

The objective of this paper is to contribute to the existing literature of studies on youth transitions from education to work. Today's job candidates are not necessarily unemployed or dissatisfied with their current positions. According to Jobvite (2016), 48\% participants have used social media in the search for their current job, and 59\% have used their social 
media accounts to follow their future company and assess the organizational culture of their potential employers. This paper's next section is a review of literature of significant studies that explore the new breed of job candidates who are born and raised digital.

\section{Literature review}

Through an exhaustive literature review, this paper maps the following areas for future research in social media and its various applications in business and specifically in human resources management. First, it aims to define digital natives and understand their behavioral patterns. Second, the paper explores the youth transitions from education to work by discussing the concepts of uncertainty and risk. Third, the paper discusses the significant studies that investigate ways and techniques to cope with recruitment uncertainty. Forth, social media recruitment is an area that this paper explores through a critical review of literature. Finally, this paper concludes that social media has the potential to reduce uncertainty and to offer unique occupational opportunities through online personal branding.

1.1. Digital natives. Most of the current job candidates are members of the generations $\mathrm{X}$ and $\mathrm{Y}$. Both generational groups grew up in the digital era and experienced first-hand the rapid proliferation of technology. Digital natives are "children who were born later than 1980 and raised in the digital world" (Prensky, 2001, p. 1). They grew up experiencing certain technological advances such as increase of personal computers market, internet revolution, vast adoption of laptops, birth of social media, growth of mobile devices, and recent development of wearable items. Digital natives are eager to be the first to use the new technological gadgets like mobile devices and other wearable items. They enjoy social media entertainment services such as YouTube, Netflix, and Spotify; they read the news by following web links and hashtags on Twitter and Instagram, while they maintain their Linkedin accounts only for business. The modern digital natives blur the lines between their personal and public spaces, as they recognize great opportunities in increasing their social and business contacts to assist their transition to the professional world (Papakonstantinidis, 2014).

Until recently, the process of employment followed a specific routine. Candidates started by searching in the newspaper's job ads section. If this did not work out, then the candidates would consult a job agency, and start sending their resumes in any possible direction (Walker et al., 2010). Today, those who wish to stand out in a crowded business environment, adopt alternative and innovative methods. Job candidates are searching for jobs anytime and anywhere as $52 \%$ of job seekers have looked for a job through their mobile device and while in bed, and 37\% answered that they searched for new employment, while they were at the office their current job (Jobvite, 2016). A simple search on YouTube offers plenty of examples of prospective employees who advertise their skills through self-made videos.

Nowadays, career offices and agency firms find significant support from social networking sites like Facebook and LinkedIn. While the former can be dangerous, and nobody wants his/her future boss to see private photos from the summer drunkenness, the second site, LinkedIn, specializes in business contacts and acquaintances. After its acquisition by Microsoft, LinkedIn claimed 500 million users and 10 million job postings (Darrow, 2017). LinkedIn has gained popularity among professionals in a variety of industries. Most interesting are that "over $80 \%$ is using LinkedIn as a primary tool to find employees, while simultaneously $70 \%$ is using the social media platform for job-hunting worldwide" (Most famous social network sites worldwide as of September 2017).

Do all digital natives use social media to reduce uncertainty when it comes to employment prospects? Not all "digital natives make a clear distinction between the use of social media for social and professional purposes" (Papakonstantinidis, 2014, p. 18). Specific behaviors on social media reveal that different personalities of users such as the Denials, the Socializers, the Contributors, and the Achievers are still not using social media in the same way (Papakonstantinidis, 2014). With the use of social media platforms, the job candidates can interact directly with the employers without using job agencies as liaisons (Crompton \& Sautter, 2011). The modern job seekers aim to reduce uncertainty by searching for more information regarding the company they apply (Walker et al., 2013). Not only they visit the company's website, but they search for reviews, comments, and even salary ranges on social media.

Whether they are university graduates or unemployed/employed workers, job candidates seem to be more puzzled than ever. Today's labor landscape offers countless opportunities to work, either as onsite or remote employees or even as young entrepreneurs who can take advantage of the new technologies to start their own business. The next section offers a review of the literature about young people's transition from being students to being professionals.

\subsection{Youth transitions from education to work.} The youth transition from education to a professional environment is not a linear process anymore. It requires a lot more than just good education (Good- 
win \& O'Conor, 2003). Young people argue that getting a university degree is just not enough. In the documentary film "My Millennial Life," one of the interviewees say that "having an education now is like having a cell phone like everyone has one. It does not make you stand out anymore" (Judge, 2016). The young people should navigate their paths and negotiate about their professional placements individually and not collectively. Millennials represent the most educated generation in history. Since 1981 , there has been a $58 \%$ increase in the percentage of people pursuing their university degrees or diplomas (Judge, 2016).

According to the OECD (2017), the unemployment rate consists of the number of unemployed people plus those in self-employment jobs as a percentage of the labor force. Data reveal that the numbers of graduates with no work, as well as the underemployed workers in low-wage and dead-end jobs, labor youth are increasing worldwide. Also, more than nine million jobs would be offered by 2020 due to technology and automation (World Economic Forum, 2016). Soon the marketplace will offer jobs such as "chief productivity officer, excess capacity broker, drone pilot, private industry air traffic control, self-driving car mechanic, autonomous transportation specialist" (Slayter, 2017).

The contemporary notion of a risky and uncertain transition to work has multiple explanations. Yates (2005) argues that primarily, the move from manufacture to the service-oriented type of jobs has brought to surface the demand for advanced academic studies and flexible specializations. Constant and more accurate job performance evaluation increases the possibilities for failure and job loss. Millennials feel uncertain knowing that nothing is permanent anymore. Young people switch jobs and occupations as they try to find the one job that combines the right work environment, exciting projects, lack of routine, and fair salary.

The constant job hunting does not help the young graduates "develop a steady employment relationship until many years after school, if at all" (Yates, 2005 , p. 21). Young people delay the time to leave home and set up their own lives. Taylor (2008) argues that young people tend to extend their academic studies for two reasons. The one reason is to postpone their admission to the professional world and the second reason is to satisfy the general belief that the educated people receive more job offers. Therefore, as Yates (2005) argues, the time college students spend in the university has increased to maximize their acquired knowledge while minimizing the notion of an uncertain transition to work.

In the past, students' professional employment deci- sions were direct (Ashton \& Field, 1976). This notion is not the case anymore as the employment environment turn out to be complicated due to the abundance of job options (Yates, 2005). Forty years later, the route from higher education to paid employment is often depicted as long lasting and unsafe that takes a lot of effort and patience to get a job that fits the applicant's expectations, if ever (Lechner et al., 2016). Carr (2016) argues that information seeking via social media is significant to reduce uncertainty, as today's college graduates seem to hesitate to work without acquiring more academic credentials and receiving updated training.

According to the CEDEFOP's (2012) report on the labor market outcomes of vocational education and training, the young people receive on-going professional training to prepare themselves for the realities of the working world. The latter report implies that young people who have just finished their studies are still considered by the working world as not ready for the real challenges they will face at work. This leads us to the discussion of an oxymoron regarding the role education plays in a student's life. From the one side, education helps the young person in the smooth transition to work. On the other side, the professional world slightly neglects what students learn in school and trains the young workers again according to their rules and criteria.

Modern schools aim to provide their students with a first-hand experience from the business environment using apprenticeships (Sadler et al., 2010). There is a current debate regarding the use of such experience-based training programs. To the one end, apprenticeships are considered as wasteful exercises and to the other end of valuable lessons for the young student (Sadler et al., 2010). Nowadays, the service-oriented business sector does not allow the trainee to stay for more than a few months on a training stage. The contemporary business requires people who learn and act fast.

Modern apprenticeships failed to provide valuable training to young workers (Fuller \& Unwin, 2003). The realization that school education is not enough to provide the young worker a full image of the business world adds to the notion of uncertainty. Young workers take risky decisions knowing that their educational background is not a prerequisite for their professional success (Lehmann, 2004). Therefore, individuals need to know how to adapt to each job's requirements to gain advantage compared to other applicants.

More specified education (post-graduate) has replaced long-term apprenticeship to minimize the youth's level of uncertainty (Sadler et al., 2010). There is a general notion among the youth that the 
more degrees and credentials they can acquire, the more chances they have to get a better job and salary. Young graduates are qualified to practice a wide variety of professional tasks and to be ready to work in a flexible labor landscape with on-site and online occupations. Though, companies consider education as static and always one step behind the actual professional expectations (Fuller \& Unwin, 2003).

This paper discusses how digital natives use the social media to extract adequate information during their transition to the labor market. Recruiting the best talent remains an essential aspect of companies and organizations. Organizations should "carefully manage their communications throughout the recruitment process" (Walker et al., 2013, p. 1325) and take into consideration the levels of uncertainty among the job candidates. The next section offers a review of publications regarding recruitment uncertainty in youth professional transitions.

1.3. Recruitment uncertainty. Berger and Calabrese (1975) developed from the post-positivist tradition the uncertainty reduction theory to explain the need for people to collect as much information as possible before their initial interaction with others. Information-seeking behavior results from people's need to reduce their uncertainty (Wilson, 1999). This paper aims to offer a review of studies on how young people use social media to seek for more information to reduce their recruitment uncertainty.

Pilcher (1995) defines youth those age groups who are still living with their parents, but they are on the verge to start making their own living. They cannot be considered as students anymore, but neither as professionals. Youth have finished their studies, and they are planning to get a job. Youth's primary concern is to minimize the duration of their reasonable unemployed period as it is one of the most critical factors to generate fear and uncertainty among the college graduates (Celik, 2008). What other factors cause uncertainty among the youth?

Primarily, young people are uncertain about their career prospects (Lehmann, 2004). Most of the available first jobs in youth's professional transitions are for the career less or short-term career employees. Klein (2001) suggests that the current corporate world offers unlimited options for low paid and low responsibility jobs as the author calls them McJobs. Klein also writes that since most of the manufacturing is now located overseas, the well-educated candidates cannot find enough available jobs to practice their acquired skills. Therefore, despite the expansion of technology, human handled jobs seem to decrease.

Second, young people are uncertain about their readiness to take on responsibilities (Taylor, 2005). Young people have limited, or even sometimes no experience on the job as traditional academic education still seems to maintain the distance between what is taught in class and what is needed in a professional context. In school, the students knew that their professors were evaluating their performance in class under a specific grading scheme. Now, young graduates are asked to apply their acquired knowledge in practice. To them, it is still unclear what needs to be done to receive positive evaluations and secure their position.

Third, young people are uncertain about the evident social inequalities and gender differences at work (Goodwin \& O'Connor, 2003). For instance, although male students score lower in their school performance than girls, as working men they receive better job offers at work (Iannelli \& Smyth, 2008). The youth sense of uncertainty can be explained by the social mistreatment at work (Haase et al., 2008) and the increasingly risky, diversified and individualized professional environment (Sørensen, 2006). Gender inequalities are evident in business when it comes to men having better professional chances than women at work to meet with their career aspirations (Haase et al. 2008). Also, the latter authors argue that social mistreatment at work is evident when most of the top level positions are filled with White-Caucasian male managers.

Finally, young people are uncertain about the fierce global competition which is fueled due to the expansion of the internet (Lehmann, 2004). Young people know that they should compete in a more globalized labor landscape. According to the 2017 Careerbuilder.com survey as cited by Brooks (2017), "70 percent of employers now use social media to screen job candidates before hiring them, up from 60 percent a year ago and 11 percent in 2006". As social screening becomes a commonly used business practice, the need for professionals to use their social media profiles cautiously is increasing. This paper primarily agrees with Lechner et al. (2016) that through vocational training young people aim to minimize their recruitment uncertainty by increasing their social status. Also, this paper argues that today's digital natives turn on the internet to enhance their information and to increase their social media influence (Lampel \& Bhalla, 2007). The next section provides a review of selected articles regarding the new opportunities social media offers to digital natives.

1.4. Social media recruitment. Social entertainment and social recruitment are two rapidly proliferated trends that engage a vast number of people (Qualman, 2013). Dutta (2010) argues that the web 2.0 and particularly social media changed the world in many ways, allowing people and brands to communicate on a personal level. People came closer to 
the brand idea and inevitably, brands came closer to people. The internet is full of stories in various formats, such as blogs, video blogs, short clips, competitions, tutorials, and even social media challenges of people who seem to enjoy their online public exposure. Social media has become a tool for entertainment and communication. But, is it also a business tool which people can turn to look for occupational opportunities? To that extent, social media recruitment or as it is mentioned in many scholarly articles as social recruiting, turned out to be a convenient and cost-effective method for companies to attract and recruit not only the best talents in the market but also the most popular and social media savvy candidates (Darrow, 2017).

As people turn to the internet to find anything, Morrison (2015) argues that employers are using the social networking sites to find and recruit new employees. The past notion of the unemployed worker or the active job seeker is not so evident than before Selden and Orenstein (2011). Companies search for the best talents, whether they are already employed or not. This access to the virtual pool of candidates has opened new possibilities to human resources teams to apply social recruiting strategies and identify the most suitable candidate (Bullard, 2003). Hamid et al. (2016) argue that social recruiting is a cost-effective and time-cutting method that allow companies to find for the perfect match by just typing the right criteria in the advanced search engines of platforms such as Linkedin.com, Bayt.com or XING.com.

Social recruiting has also another side for companies. As much as recruiters can use social media to screen and recruit employees, potential candidates can do the same to companies (Beardwell \& Claydon, 2007). People use the internet and social media to look for either another job if they are currently employed (Hooley, 2012). Also, the use of social media by both individuals and companies shaped a more transparent business environment. Blogs, Twitter accounts and online platforms such as Glassdoor.com provide users with accurate employee reviews, salary ranges, and interview questions of a wide variety of companies in the world.

Social media recruitment is a crucial function and concept in contemporary business. At a time that education seems not just to be enough (Taylor, 2008), and apprenticeships fail their mission to provide valuable training to young workers (Fuller \& Unwin, 2003), the modern labor landscape is more complicated as ever. From the one side, recruiters admit that they use social screening strategies to check people's social media accounts to make their final decision (Lobvite, 2016). On the other side, academic scholars argue that the young people use social networking sites such as Facebook, Twitter, and Instagram to communicate their online identity and increase their social media influence among their friends and followers (Madge et al., 2009; Hooley, 2012). Is social recruiting the answer to reduce professional uncertainty?

Future research studies should further explore the concept of social screening and answer to what extent young people's use of social media is affected by the fact that companies openly admit that they are watching them. Ambitious and anxious to set up a successful career, young people are ready to think out of the box and make alternative decisions (Brooks \& Anumudu, 2016). Social media offers a landscape where young people can self-taught and present their skills through media-rich content, such as YouTube videos, selfies on Instagram and posts on Facebook. The paper's last section provides future research implications regarding the use of personal branding through social media as an alternative method to reduce occupational uncertainty.

Today's digital natives are mainly relying on the internet to start their career and enhance their professional future. The digital natives do not only go social; they go live. Personal branding online is a new reality and especially young people still seem to be unaware of the negative consequences of mistreating the social media (Fetscherin, 2015). For this reason, qualitative research has to explore the reasons why young people turn to social media to build their personal brand online. What are the social factors that drive people to look for professional solutions and create their own occupational opportunities through blogs and video blogs (vlogs). Is there any correlation between the sense of professional uncertainty and the increase of personal branding using the social media?

Personal branding is a somewhat new term in academic marketing literature, but it has become a growing trend that is worth to further research (Labrecque et al., 2011; Dutta, 2010). The rapid expansion and adoption of the internet and social media among the digital natives established personal branding as an emerging lifestyle (O'Brien, 2011). While a great deal of academic research has explored the impact of social media on corporate marketing and branding, the phenomenon of online personal branding is now getting to be discussed more in the literature (Chen, 2013). This paper aims to contribute to this growing trend in academic literature.

As social media, mobile devices, and local marketing integrate into today's professional and personal landscape; organizations are shifting their attention to new technologies to perform a plethora of busi- 
ness activities (Papakonstantinidis et al., 2016). Organizations comprehend the impact of social networks on marketing and human resources management as job candidates argue that the recruitment process has become more transparent and fair (Santonocito, 2009). Is however the recruitment process more transparent and fair than ever before? A study that triangulates both qualitative and quantitative data is possible to offer new directions towards the notion of selection transparency and social screening.

\section{Conclusion}

Is personal branding an effective method to reduce uncertainty regarding recruitment? Kaputa (2005) writes that personal branding offers a substantial competitive advantage as eventually, it will all come to online personal influence. Personal branding is more than a trend. In today's highly competitive professional world, personal branding allows job seekers to stand out from the rest of the job candidates by demonstrating their skills on social media platforms (Brooks \& Anumudu, 2016). Personal branding does not only offer both employed and unemployed professionals a competitive advantage in their job search. Personal branding provides people with entrepreneurial opportunities (Gandini, 2015) to become known by expressing their skills and passion on social media.

Humans can strategically manage their names as brands just as marketing experts do with products and services (Fetscherin, 2015). Papakonstantinidis (2014) defines those who are overly aware of their reputation as achievers in a native digital landscape. These goal-oriented social media users treat technology as a tool to start and strengthen their careers. The achievers are exceptionally careful when it comes to how they use the internet to protect their digital reputation. The achievers demonstrate an intrinsic need to succeed in life through their cautious online reputation management. They are cautious when using social media knowing that recruiters might be screening them. For the achievers, the use of social media is like a strategy game in which every action has a consequence.

There are many examples of individuals who became famous and rich through the use of social media by publicly displaying their skills in music, video games, sports, or cooking. For instance, Felix Arvid Ulf Kjellberg is an online video gamer with more than 57 million subscribers and over 16 billion views on his PewDiePie YouTube channel. The estimated yearly earnings of PewDiePie are more than $\$ 12$ million (Mandle, 2017). Is having an active profile (also known as a person) on social media enough to enable individuals to reduce their profes- sional uncertainty? How do successful YouTubers feel about working in companies? Does their popularity maximize or minimize their chances of starting a career in the marketplace? What happens to those social media influencers as soon as their popularity decreases and fades away?

Future research should be able to explore the means employed by young people to reduce uncertainty when it comes to their future career. Further research needs to explore to what extent a candidate's popularity might influence the recruiting process. Do companies prefer to hire popular online personas or it is more appropriate for them to hire a less social media savvy candidate? What makes them better candidates; their skills and credentials or their online reputation? What is the impact of specific tools and applications, like a YouTube video's thumbs up button or Klout's measurement of social influence on a recruiter's decision?

The future of business and recruitment is unpredictable. Social media is used both as tools to screen and recruit candidates, as well as employee referral programs. With the rapid development of new online tools, technology will continue shaping a new professional landscape in human resources. How can social media and personal branding affect traditional business processes? Developing and protecting one's reputation in social media has become vital and beneficial not only for the young recruits but also for their organizations. To what extent an employee with a carefully maintained online reputation can aid or damage a brand's reputation? How do organizations consider their online celebrity employees? Are they a treat or a competitive advantage in today's professional landscape? A study that explores the questions above and re-defines the sense of confidentiality between organizations and employees would be highly beneficial.

Through a systematic review of the literature, this paper concludes that the increased and ubiquitous use of social media as a means of information, communication, and entertainment is shaping the future work reality. This review paper identifies some unexplored areas in the literature as more studies have been conducted by trade and online publications about personal branding and social recruiting than in academia. In other words, more empirical research should investigate the impact of personal branding through social media as a method to reduce recruitment uncertainty. This paper aims to alert the academic scholars to research in-depth the social factors and the business communication dynamics that take place due to the increased use of social media in the workplace. 


\section{References}

1. Ashton, D., \& Field, D. (1976). Young workers. London: Hutchinson.

2. Beardwell, J., \& Claydon, T. (2007). Human resource management: A contemporary approach. Harlow, England: Prentice Hall/Financial Times.

3. Berger, C. R., Calabrese, R. J. (1975). Some exploration of initial interaction and beyond: Toward a developmental theory of communication. Human Communication Research, 1, 99-112.

4. Bohlinger, S., Haake, U., Jørgensen, C., Toiviainen, H., \& Wallo, A. (2015). Working and learning in times of uncertainty. Rotterdam. The Netherlands: Sense Publishers.

5. Brooks, A. K., \& Anumudu, C. (2016). Identity development in personal branding instruction. Adult Learning, 27(1), 23-29. https://doi.org/10.1177/1045159515616968

6. Brooks, C. (2017). Keep it clean: Social media screenings gain in popularity. Business News Weekly. Retrieved from https://www.businessnewsdaily.com/2377-social-media-hiring.html (accessed on December 15, 2017).

7. Carr, C. T. (2016). An uncertainty reduction approach to applicant information-seeking in social media: Effects on attributions and hiring. In R. Landers \& Schmidt G. (Eds.), Social Media in Employee Selection and Recruitment. Springer, Cham.

8. Carr, C. T., \& Walther, J. B. (2014). Increasing attributional certainty via social media: Learning about others one bit at a time. Journal of Computer-Mediated Communication, 19, 922-937. https://doi.org/10.1111/jcc4.12072

9. CEDEFOP (2012). From education to working life: The labor market outcomes of vocational education and training. CEDEFOP Reference series Luxemburg: Office for Official Publications of the European Communities.

10. Celik, K. (2008). My state is my father: Youth unemployment experiences under the weak state welfare provisions of Turkey. Journal of Youth Studies, 11(4), 429-444.

11. Chen, C. (2013). Exploring personal branding on YouTube. Journal of Internet Commerce, 12(4), 332-347. http://dx.doi.org/10.1080/15332861.2013.859041

12. Crompton, D., \& Sautter, E. (2011). Find a job through social networking: Use Linkedin, Twitter, Facebook, blogs and more to advance your career. St. Paul, MN: Jist Works.

13. Darrow, B. (2017). LinkedIn claims half a billion users. Fortune Magazine. Retrieved from http://fortune.com/2017/04/24/linkedin-users/ (accessed on September 25, 2017).

14. Dutta, S. (2010). What's your personal social media strategy? Harvard Business Review, 88(11), 127-130.

15. Fetscherin, M. (2015). The CEO branding mix. Journal of Business Strategy, 36(6), 22-28. https://doi.org/10.1108/JBS-01-2015-0004

16. Fuller, A., \& Unwin, L. (2003). Creating a "Modern Apprenticeship": A critique of the UK's multi-sector, social inclusion approach. Journal of Education and Work, 16(1). https://doi.org/10.1080/1363908022000032867

17. Gandini, A. (2015). Digital work. Marketing Theory, 16(1), 123-141.http://dx.doi.org/10.1177/1470593115607942

18. Goodwin, J., \& O'Connor, H. (2003). Exploring Complex Transitions: Looking Back at the 'Golden Age' of From School to Work. ESRC Youth Worker Project Research Paper 5, Leicester Center for Labor Market Studies, University of Leicester.

19. Haase, C. M., Heckhausen, J., \& Koeller, O. (2008). Goal engagement during the school-work transition: Beneficial for all, particularly for girls. Journal of Research on Adolescence, 18(4), 671-698.

20. Hamid, S., Bukhari, S., Ravana, S., Norman, A., \& Ijab, M. (2016). Role of social media in information-seeking behaviour of international students. Aslib Journal of Information Management, 68(5), 643-666. https://doi.org/10.1108/ajim-03-2016-0031

21. Hillmert, S., \& Jacob, M. (2003). Multiple episodes: Training careers in a learning society. Paper presented at the Transitions in Youth Conference, Competencies and Careers, 4-6 September 2003, Funchal, Madeira.

22. Hooley, T. (2012). How the internet changed career: framing the relationship between career development and online technologies. Journal of the National Institute for Career Education and Counselling (NICEC), 29, 3-12.

23. Iannelli, C., Smyth, E. (2008). Mapping gender and social background differences in education and youth transitions across Europe. Journal of Youth Studies, 11(2), 213-232.

24. Jobvite (2016). The annual social recruiting survey. Retrieved from https://www.jobvite.com/wpcontent/uploads/2016/09/RecruiterNation2016.pdf (accessed on October 5, 2017).

25. Judge, M. (Director), Engel, C., \& Judge, M. (Producers). (2016). My Millennial Life [Video file]. Makin' Movies Inc. Retrieved on September 27, 2017 from Academic Video Online: Premium.

26. Kaputa, C. (2005). UR a brand! How smart people brand themselves for business success. Mountain View, CA: Davies-Black Publishing.

27. Klein, N. (2001). No logo. Harper Perennial: Hammersmith, London.

28. Labrecque, L. I., Markos, E., \& Milne, G. R (2011). Online personal branding: Processes, challenges, and implications. Journal of Interactive Marketing, 25, 37-50.

29. Lampel, J., \& Bhalla, A. (2007). The role of status seeking in online communities: Giving the gift of experience. Journal of Computer-Mediated Communication, 12(2) 434-455. Retrieved from http://jcmc.indiana.edu/vol12/issue12/lampel.html

30. Lechner, C. M., Tomasik, M. J., \& Silbereisen, R. K. (2016). Preparing for uncertain careers: How youth deal with growing occupational uncertainties before the education-to-work transition. Journal of Vocational Behavior, 95, 90-101. https://doi.org/10.1016/j.jvb.2016.08.002 
31. Lehmann, W. (2004). For some reason, I get a little scared: Structure, agency, and risk in school-work transitions. Journal of Youth Studies, 7(4), 379-396.

32. Madge, C., Meek, J., Wellens, J., \& Hooley, T. (2009). Facebook, social integration and informal learning at university: It is more for socialising and talking to friends about work than for actually doing work. Learning, Media and Technology, 34(2), 141-151.

33. Mandle, C. (2017). TheYouTuber who has made more money than Cameron Diaz this year. The Independent. Retrieved from http://www.independent.co.uk/news/people/forbes-names-pewdiepie-as-highest-earning-youtuberwith-annual-income-reaching-12m-a6695536.html (accessed on October 12, 2017).

34. Morrison, K. (2017). Survey: $92 \%$ of recruiters use social media to find high-quality candidates. Adweek.com. Retrieved from http:/www.adweek.com/digital/survey-96-of-recruiters-use-social-media-to-find-high-qualitycandidates/ (accessed on October 2, 2017)

35. Most famous social network sites worldwide as of September 2017. (2017). Global social media ranking $2017 \mid$ Statistic. Statista. Retrieved from https://www.statista.com/statistics/272014/global-social-networks-ranked-bynumber-of-users/ (accessed on October 11, 2017).

36. O'Brien, C. (2011). The emergence of the social media empowered consumer. Irish Marketing Review, 21(1), 32-40.

37. OECD (2017). Unemployment rate in 2017. The Organisation for Economic Co-operation and Development. https://doi.org/10.1787/997c8750-en

38. Papakonstantinidis, S. (2014). Social recruiting: Exploring the impact of social networking sites on digital natives' occupational opportunities. British Library EThOS, EBSCOhost. Retrieved from https://lra.le.ac.uk/handle/2381/28623

39. Papakonstantinidis, S., Poulis, A., \& Theodordis, P. (2016). $R$ U \#SoLoMo ready? Consumers and brands in the digital era. New York: Business Expert Press.

40. Parch, K. E., Nelson, M. C., Lytle, L. A., Moe, S. G., \& Perry, C. L. (2008). Adoption of risk-related factors through early adolescence: Associations with weight status and implications for causal mechanisms. Journal of Adolescent Health, 43(4), 387-393.

41. Pilcher, J. (1995). Age and generation in modern Britain. Oxford: Oxford University Press.

42. Qualman, E. (2013). Socialnomics. Hoboken, NJ: Wiley.

43. Sadler, T. D., Burgin, S., McKinney, L., \& Ponjuan, L. (2010). Learning science through research apprenticeships: A critical review of the literature. Journal of Research in Science Teaching, 47, 235-256. https://doi.org/10.1002/tea.20326

44. Santonocito, P. (2009). Online social networking: What it really means to employee recruitment. Online Recruitment Magazine. Retrieved from http://www.onrec.com/newsstories/20445.asp (accessed on September 10, 2017).

45. Selden, S., \& Orenstein, J. (2011). Government e-recruiting web sites: The influence of e-recruitment content and usability on recruiting and hiring outcomes in US state governments. International Journal of Selection and Assessment, 19(1), 31-40.

46. Slayter, M. (2017). 11 really cool jobs that don't exist today, but will soon. Retrieved from https://www.monster.com/career-advice/article/cool-future-jobs (accessed on October 5, 2017).

47. Sorensen, A. (2006). Book Review: Young People in Risk Society: The Restructuring of Youth Identities and Transitions in Late Modernity. YOUNG, 14(2), 171-173. http://dx.doi.org/10.1177/110330880601400209

48. Strathdee, R. (2001). Changes in social capital and school-to-work transitions. Work, Employment and Society, 15(2), 311-326. https://doi.org/10.1177/09500170122118977

49. Taylor, A. (2005). What employers look for: the skills debate and the fit with youth perceptions. Journal of Education and Work, 18(2), 201-218.

50. Taylor, A. (2008). You have to have that in your nature: Understanding the trajectories of youth apprentices. Journal of Youth Studies, 11(4), 393-411.

51. Walker, H., Bauer, T., Cole, M., Bernerth, J., Feild, H., \& Short, J. (2012). Is this how I will be treated? Reducing uncertainty through recruitment interactions. Academy of Management Journal, 56(5), 1325-1347. http://dx.doi.org/10.5465/amj.2011.0196

52. Walther, A. (2008). De-standardisation of youth transitions: Challenges for youth work. Paper Presented at the $4^{\text {th }}$ Estonian Youth Work Forum, 21-22 October 2008 Tallinn, Estonia.

53. Wilson, T. D. (1999). Models in information behaviour research. The Journal of Documentation,55(3), $249-270$.

54. World Economic Forum (2016). The Future of jobs employment, skills and workforce strategy for the fourth industrial revolution. Retrieved from http://www3.weforum.org/docs/WEF_FOJ_Executive_Summary_Jobs.pdf (accessed on October 5, 2017).

55. Yates, J. A. (2005). Transition from school to work: Education and work experiences. Monthly Labor Review, $128(2), 21-32$. 